\title{
Learning Mathematics with Contextual Approach to Improve Outcomes Learning Maths in Vocational High School
}

\author{
Ani Ainun Masruroh1, Rani Oktaviani2, Sri Islami Kulsum³ ${ }^{3}$ M. Afrilianto4 \\ 1,2,3,4Pendidikan Matematika, IKIP Siliwangi, Indonesia \\ 19aniainun20@gmail.com, ${ }^{2}$ ranioktaviani1997@gmail.com, ${ }^{3}$ sriislamikulsum@gmail.com, \\ 는
}

\begin{abstract}
Article History:

Received : 26-02-2020

Revised $1: 12-03-2020$

Revised 2 : 26-03-2020

Accepted : 28-03-2020

Online : :02-04-2020

Keyword:

Action Research; Contextual Approach; Learning Outcomes.

This research aims to improve student learning outcomes on mathematics learning by using a contextual approach. This research is a Class Action Research (CAR) conducted at one of the vocational schools (SMK) in X-class areas of focus on Automation of Governance and Office 3. The research instruments used in this study are (1) tests consisting of pre-test and post-test of the concept of Sigma notation and infinite series; and (2) the use of an observation sheet for teachers and students as a condition of measuring action execution. The procedure of the study consists of (1) planning, (2) The implementation of Action, (3) observation, (4) evaluation, and (5) reflection. The test results showed that there was an increase in pre-test and post-test results of $19.33 \%$. Obviously, this shows that students ' learning outcomes on math learning are increasing after learning using a contextual approach.
\end{abstract}

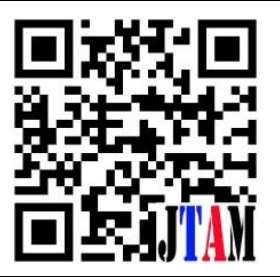

dol Crossref 1 (C) () ()

$\underline{\text { https://doi.org/10.31764/jtam.v4i1.1870 }}$ This is an open access article under the CC-BY-SA license

\section{A. INTRODUCTION}

Kartikaningtyas et al., (2018) said mathematics is about thinking, organizing, and also a logic proofing. Because of that, the position of mathematics in education is very beneficial because mathematics is a tool in the education, intelligence and has a significant influence on the development of science and technology. Mathematics becomes a compulsory in every school unit including vocational high school (SMK). Problems in learning mathematics always appear that the reluctance of students to learn (Felmer, Pehkonen, \& Kilpatrick, 2016). This is due to the learning process of mathematics that is struggling with the formula. Also, students do not know the impact or the direct use of mathematics in everyday life become lazy excuse students to learn mathematics. Thus affecting the results of students' mathematics learning.

Lipianto in Sumadiasa (2014) said mathematics education has a very important role because math is basic science that is widely used in various fields of life. Through the study of mathematics, students are expected to foster critical thinking skills, logical, precise, effective 
and efficient in solving problems (Ter Berg \& Van Der Brugge, 2013), (Su, Ricci, \& Mnatsakanian, 2015). Learning mathematics is a continuous process for obtaining concepts, ideas and new knowledge based on previous experiences (Taleb, Ahmadi, \& Musavi, 2015).

The mathematics learning process must be delivered regularly. Material presented should be arranged regularly in a logical order (hierarchical) in the sense that the topic would be a prerequisite for the next topic. Therefore, before mastering the next topic of the material we must master the material in advance before. Hierarchy of mathematics is mathematics discontinuous would disrupt the learning process. This means that learning mathematics must be continuous (Arviv-Elyashiv \& Gal, 2017).

Results of observation by Anwar (2017) conducted found result from learn math arithmetic sequence and series of material is still low, this is due to several factors, including the student's ability to make sense of the patterns and the use of less appropriate learning strategies so that learning is less run with the maximum and optimal. Moreover, Hoogland, Pepin, de Koning, Bakker, \& Gravemeijer (2018) said many studies that report serious difficulties with the use of word problems in the mathematics classroom. The most reported difficulty is that students do not take into account common sense considerations about the problem, which affects the processes off or emulating the mathematical problem, and interpreting the mathematical results. As a consequence, many students fail to solve the posed problems correctly.

In line with the above observations by Oktavianingsih, Maharani, \& Wahyuni (2019), Mistakes are often made by students in solving the material sequence and series is not exactly the procedure used, the error because students forget a formula, not understand the sequence and series of material with a large percentage of $34.06 \%$, resulting in student's proficiency level error category one in determining the settlement. From this problems, the authors researched in one of the SMK with line and sequences material using learning that makes students interested and more knowledgeable in learning mathematics is the contextual approach.

\section{B. METHOD}

This type of research is classroom action research. This classroom action research consisted of two cycles, each cycle consisting of planning, action, observation, and reflection. Suyitno (Hendriana \& Afrilianto, 2014) said that PTK or so-called Classroom Action Research (CAR) is a systematic study done by teachers to improve practices in education with practical action and reflection of the action. Arikunto, Suhardjono, \& Supardi (2015) said class action research is a form of participatory, collaborative and spiraling reflective, which can apply class actions, and perform reflections, up to the achievement of repairs or improvements following the expected. So this method is used to know the extent of student learning outcomes.

A contextual approach is one of the approaches that the learning process is connected to in real life and gives a direct example of the material being taught, it is in line with (Bevir, 2011), (Davtyan, 2014). Learning (CL) is a learning system that ties brain actions to crating patters that have meaning. CL does it by connecting academic content to the context of real life. This is very important because it helps to store not only short-term memory, which students usually 
easily forget, but it also help to store long term memory which will help them to apply these memories to their job obligations later in their life.

On the other hand, the contextual approach will help teachers in the learning process as delivered (Ekowati, Darwis, Upa, \& Tahmir, 2015). Contextual approach is a concept which helps teachers to learn and to associate the content-studied with the real-world situations of students and encourage students to make connections between the knowledge possessed by its application in their lives as members of families and communities. With that concept, the outcome of learning is expected to be more meaningful for students. The learning process takes place naturally in the form of student activities and work experience, not a transferring of knowledge from teacher to student. Strategy of learning is more important than the outcome. As other learning strategies, contextual learning is developed with the aim to be more productive and meaningful. Contextual approach can be run without having to change the curriculum and the existing order.

Sutrisno \& Siswanto (2016) said reveals learning outcomes is an evaluation activity that can reveal the aspect of the thought process (cognitive domain) can also uncover other psychiatric aspects, i.e. aspects of value or attitude (domain effective) and aspects Skills (psychomotor domains) attached to each learner. The result of learning according to Sjukur, (2013) is a final assessment of the process and the introduction that has been done repeatedly and will be stored for a long time or will not even be lost forever because the results of learning participate in forming individuals who always want to achieve even better results that will change the way of thinking and produce better work behavior.

In the process, class action research has a cycle, where one cycle contains two learning meetings. In this study, researchers used two cycles. It is done so that the purpose of this research can be achieved. The object of this research is the grade X students of the automation of governance and office in SMK Cendekia Batujajar West Bandung Regency with the number of students as much as 36 people with the material about Sigma notation and the infinite series and using two cycles Class Action Research. The steps used of each cycle are from planning, implementation of action, observation, evaluation, and reflection. The process of collecting data in this research using the instruments of pre-test, post-test and observation sheets.

\section{RESULT AND DISCUTION}

This study begins with preliminary observations during the implementation of the environmental Introduction of schooling (Pengenalan Lingkungan Persekolahan) held from 19 August until November 9, 2019. The results of the observation showed that the problems perceived by teachers are the difficulty in implementing appropriate learning approaches that can enhance students' knowledge of mathematics equally.

Another problem faced by teachers during the learning of mathematics is enthusiastic students in the course. Not a few students thought that learning mathematics is considered unnecessary and just a headache only. Based on these observations, researchers and teachers of subjects agreed to try using a contextual approach in the learning process in the classroom. It was based on a real show regarding the use of mathematics to the students so that the students will learn enthusiastic better which will affect learning results in getting. 
Before entering the action phase, researchers conducted initial tests in advance to determine the extent of students' ability to work on the problems that they have not learned before. These preliminary tests carried out on Tuesday, November 12, 2019, this will be the reference test whether there is any change after learning that uses a contextual approach later.

The results of the initial tests showed a pretty good value, with an average of 75.75 following the KKM mathematics at the school.

\section{Result of Cycle 1}

First stage is planning. The planning stage is the stage where researchers prepared learning tools such as lesson plan (RPP) and teaching materials as well as the observation sheet that will be used to collect data from research conducted. In this cycle, there are two meetings. Each meeting is designed following the steps listed on the approach to be used. In addition to other preparatory learning tools that strengthen knowledge and understanding of learning with the contextual approach. After that, researcher do implementation of action. It is done directly by the researcher and witnessed by subject teachers who acted as an observer. Cycle 1 will be done twice meetings. The first class meeting held on Friday, 15 November 2019 with the matter "understanding and sigma notation" using a contextual approach.

The learning activities begin with a preamble consisting of a greeting and apperception. Further division of the group (step contextual learning community) where each group consists of 5-6 people. Each group is given a student worksheet (LKS) which is included in the LKS kontuktivisme process, modeling and inquiry. Group discussions carried out for approximately 30 minutes, after discussion the student representatives of the group presented the results of group discussion in class to assess what kind of response in each group (step contextual actual votes). After that summed together on the material learned from the student worksheet (step contextual reflection). The move is following the main components of Contextual teaching and learning approach in teaching to create an effective teaching and learning process. The contextual approach step is: (Selvianiresa \& Prabawanto, 2017) first, constructivism is a philosophical thinking of contextual teaching and learning. Second, component that questioning. Questioning is the primary strategy of teaching and learning based on contextual approach. Third, Inquiry is the core of teaching and learning activity using contextual teaching and learning approach. The knowledge and skills got by the students are not only the result of remembering a set of facts, but it is a result of their own discovering. Fourth, learning community suggests the result of teaching and learning got from cooperation with other. Fifth, modeling was imitated by student is better in teaching the skill and learning the certain knowledge. The model gives the great chance for teacher to give the examples how something works before the students do the duty. Sixth, reflection is a way of thinking about what something is newly studied, thinking to the back about what we had been done on studying in the past. Seventh, authentic assessment. The assessment is the process of collecting data, which can gives a description of the students' learning. After the study concluded closed with conveying the material to be studied further and pray.

The second meeting was held on Tuesday 19 November 2019 presenting "the properties of sigma notation". Learning as usual in the open with a greeting and apperception. After the division of the group to which each group consists of 5-6 people. Each working group worksheet is given, in the LKS students are led to discover the properties and verification of 
these properties. Sift material properties sigma notation requires a long discussion that was wasting hours of lessons and therefore the second meeting was no presentation from each group. After the group finished learning discussion then closed with a greeting.

Evaluation of the results of observations during the first two meetings stated that students begin to enthusiastically follow the lesson is in progress. But it still feels less favorable when learning is done by groups.

\section{Result of Cycle 2}

Learning begins with the opening, as usual, the materials studied in this second meeting is "infinite series: converging". Grouping students in the fox so that the group is different from the previous group is done so that students can work with the new group of friends and is expected to be more favorable compared with the group on previous learning. After grouping students back discussion on worksheets provided.

Discussions went well. Interaction among fellow students and teachers (researchers) are good, it is evident from the question and answer between students and teachers. Enthusiastic students were no changes that cause the absence of actual stages in the learning assessment.

At the second meeting of the material presented is "infinite series: divergent". Learning begins with a preamble that contained its apperception. Then proceed with the grouping of students until the end of the cover. The second meeting is following the lesson plan that had been developed by previous researchers. Once the research is completed, then do a final test to see how far the students' learning outcomes obtained using a contextual approach.

\section{Reflection}

Here is one example of the work of students who have increased the value of the test results pre-test and post-test score 55 to 90 .



Figure 1. Result of Pre-test 


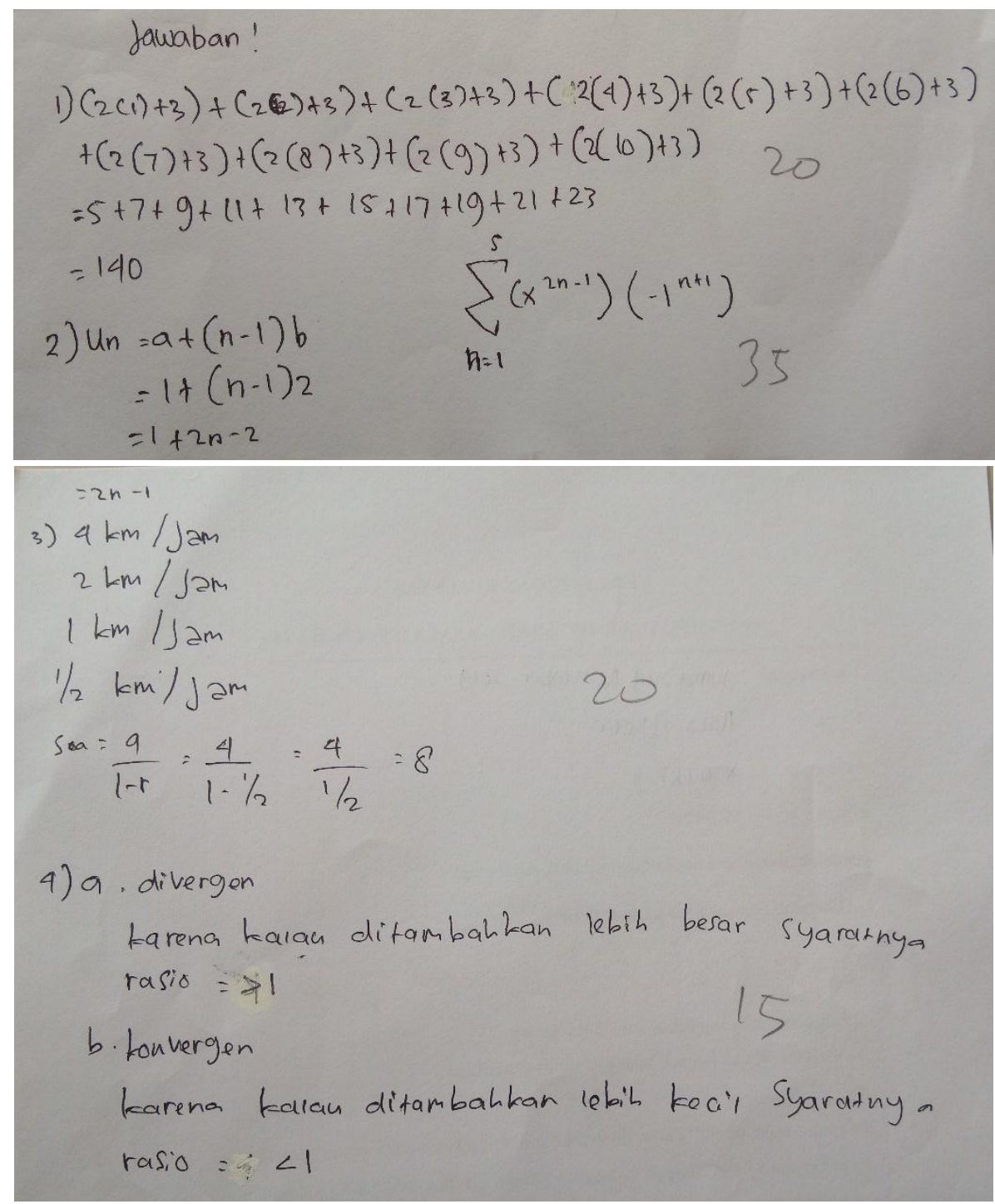

Figure 2. Result of Post-test

Learning results obtained from these studies showed an increase in the average value of the class. When at the beginning of the meeting got an average of 75.75 after learning by using a contextual approach to the final result with an average of 90.39. As illustrated in the charts below:

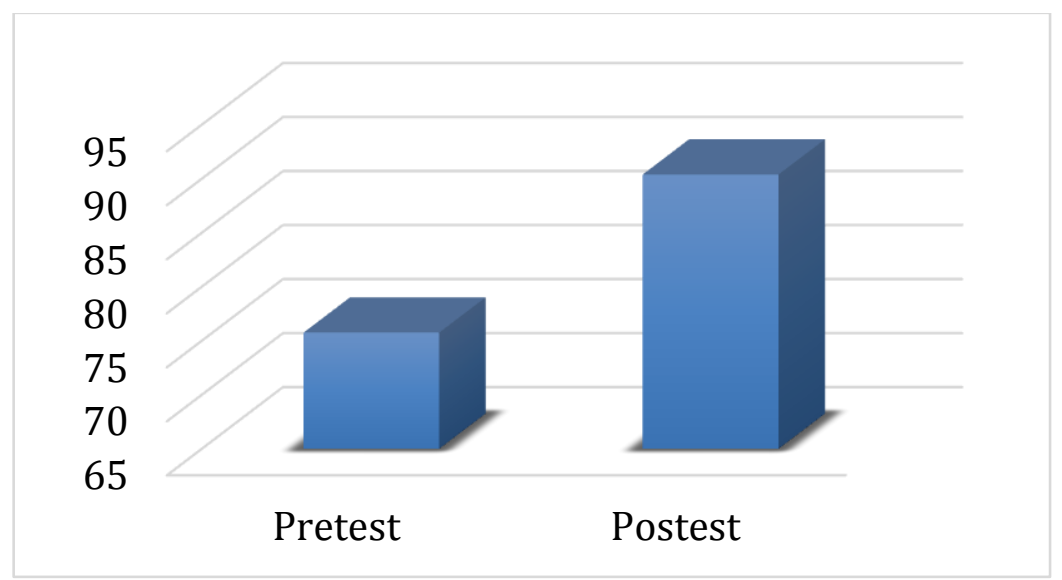

Figure 3. The Bar Chart is Average Result of Pre-test and Post-test 
It can be seen if the average increase student learning outcomes which rose as much as 14.64 average pretest score of 75.75 and the average post-test results is equal to 90.39 . The increase makes the value of students in X (the automation of governance and office) 3 existing KKM value that is equal to 75. In line with research conducted by (Panjaitan, 2016) which states that the contextual approach can improve student learning outcomes. Furthermore, this statement is reinforced by research conducted by (Palengka, 2014) that after the students learn to use a contextual approach the average value was changed from 29.15 becomes 72.4, which means the results are categorized as high. It demonstrates the application of contextual effective in improving student learning outcomes.

\section{CONCLUSION AND SUGGESTIONS}

Based on the results presented above, we get a conclusion that the use of a contextual approach in learning can improve students' mathematics learning outcomes. It can be seen from the results obtained when the pre-test and post-test, where the value of the first students increased an average student at the time of the pre-test of 75.75 into 90.39 during the post-test. Besides the communication between students, students and teachers are good, so that learning can take place smoothly.

Mathematics learning in schools should be able to use contextual learning models that have proven to be effective. For the next researcher, to examine more broadly contextual learning models viewed from different perspectives or combine that's with any learning models.

\section{ACKNOWLEDGEMENT}

This study could not be separated from the help and support of many parties to the thank-you goes to our university IKIP Siliwangi, SMK Cendekia Batujajar and all those who cannot mention one by one.

\section{REFERENCES}

Anwar, H. (2017). Hasil Belajar Barisan dan Deret Aritmatika Melalui Pembelajaran Skrip Kooperatif. Jurnal Penelitian Tindakan Dan Pendidikan, 3(2), 113-122.

Arikunto, S., Suhardjono, \& Supardi. (2015). Penelitian Tindakan Kelas (Revisi; Suryani, Ed.). Jakarta: PT Bumi Aksara.

Arviv-Elyashiv, R., \& Gal, A. (2017). Hierarchy of Needs of Persistent Mathematics and Science Teachers. American Journal of Educational Research, 5(7), 683-693. https://doi.org/10.12691/education-5-7-1

Bevir, M. (2011). The Contextual Approach. In The Oxford Handbook of the History of Political Philosophy. https://doi.org/10.1093/oxfordhb/9780199238804.003.0001

Davtyan, R. (2014). Contextual Learning. ASEE 2014 Zone I Conference, University of Bridgeport. United State of America.

Ekowati, C. K., Darwis, M., Upa, H. M. D. P., \& Tahmir, S. (2015). The Application of Contextual Approach in Learning Mathematics to Improve Students Motivation At SMPN 1 Kupang. International Education Studies, 8(8), 81-86. https://doi.org/10.5539/ies.v8n8p81

Felmer, P., Pehkonen, E., \& Kilpatrick, J. (2016). Posing and Solving Mathematical Problems : Advances and New Perspectives. In Springer Nature. https://doi.org/10.1007/978-3-319-28023-3_20 
Hendriana, H., \& Afrilianto, M. (2014). Pengabdian bagi Guru Penelitian Tindakan Kelas suatu Karya Tulis Ilmiah (Cetakan Pe; D. Sumayyah, Ed.). Bandung: PT Refika Aditama.

Hoogland, K., Pepin, B., de Koning, J., Bakker, A., \& Gravemeijer, K. (2018). Word Problems Versus Image-rich Problems: an Analysis of Effects of Task Characteristics on Students' Performance on Contextual Mathematics Problems. Research in Mathematics Education, 20(1), 37-52. https://doi.org/10.1080/14794802.2017.1413414

Kartikaningtyas, V., Kusmayadi, T. A., \& Riyadi, R. (2018). The effect of brain based learning with contextual approach viewed from adversity quotient. Journal of Physics: Conference Series, 1022(1). https://doi.org/10.1088/1742-6596/1022/1/012014

Oktavianingsih, Maharani, \& Wahyuni. (2019). Analisis kesalahan dalam menyelesaikan soal barisan dan deret berdasarkan kategori watson. Gema Wiralodra, 10(2), 253-262.

Palengka, I. (2014). Efektivitas Pendekatan Kontekstual untuk Meningkatkan Hasil Belajar Siswa Kelas VIII SMP Kristen Kandora. Jurnal KIP, III(2), 575-581.

Panjaitan, D. J. (2016). Penerapan Pendekatan Contextual Teaching and Learning (CTL) untuk Meningkatkan Hasil Belajar Statistik. Jurnal Penelitian Pendidikan MIPA, Vol. 1(No. 1).

Selvianiresa, D., \& Prabawanto, S. (2017). Contextual Teaching and Learning Approach of Mathematics in Primary Schools. Journal of Physics: Conference Series, 895(1). https://doi.org/10.1088/17426596/895/1/012171

Sjukur, S. B. (2013). Pengaruh Blended Learning terhadap Motivasi Belajar dan Hasil Belajar Siswa di Tingkat SMK. Jurnal Pendidikan Vokasi, 2(3), 368-378. https://doi.org/10.21831/jpv.v2i3.1043

Su, H. F. H. "Angie," Ricci, F. A., \& Mnatsakanian, M. (2015). Mathematical Teaching Strategies: Pathways to Critical Thinking and Metacognition. International Journal of Research in Education and Science, 2(1), 190. https://doi.org/10.21890/ijres.57796

Sumadiasa, I. G. (2014). Analisis Kesalahan Siswa Kelas VIII SMP Negeri 5 Dolo dalam Menyelesaikan Soal Luas Permukaan dan Volume Limas. Jurnal Elektronik Pendidikan Matematika Tadulako, Volume 01(No. 2), 184-207.

Sutrisno, V. L. P., \& Siswanto, B. T. (2016). Faktor-Faktor yang Mempengaruhi Hasil Belajar Siswa Pada Pembelajaran Praktik Kelistrikan Otomotif SMK di Kota Yogyakarta. Jurnal Pendidikan Vokasi, 6(1), 111. https://doi.org/10.21831/jpv.v6i1.8118

Taleb, Z., Ahmadi, A., \& Musavi, M. (2015). The Effect of M-learning on Mathematics Learning. Procedia - Social and Behavioral Sciences, 171, 83-89. https://doi.org/10.1016/j.sbspro.2015.01.092

Ter Berg, T., \& Van Der Brugge, E. (2013). Teaching Critical Thinking With Rationale. 7th International Technology, Education and Development Conference, 5145-5150. 